\title{
Anti-anaemic, haemostatic and other medicinal plants used in Tiv traditional medicine
}

\author{
Nahandoo Ichoron ${ }^{1 *}$, Michael Nor ${ }^{1}$, Ngutor Stephen Tsenongo ${ }^{1}$, Ngozichukwuka Peace Igoli ${ }^{2}$, \\ Terrumun Amom Tor-Anyiin ${ }^{1}$ and John Ogbaji Igoli ${ }^{1}$
}

${ }^{1}$ Department of Chemistry, University of Agriculture PMB 2373 Makurdi, Nigeria

${ }^{2}$ Centre for Food Technology and Research, Benue State University, Makurdi, Nigeria

*Corresponding Author: nannchoron@gmail.com

\begin{abstract}
An ethnobotanical survey of plants used in treating anaemia, haemostasis and other diseases in Tiv traditional medicine was carried out. Seventy-six traditional medicine practitioners in Gboko, Konshisha and Ushongo Local Government Areas of Benue State, Nigeria were interviewed using a structured questionnaire. Fifty-six plant species belonging to twenty-nine families were reported as being used in treating the ailments identified. Ethnobotanical indices such as Informant Consensus Factor, Use Value and Fidelity Level were used to analyze the data. The results showed that Jatropha tanjorensis, Vernonia amygdalina, Telfairia occidentalis, and Mucuna pruriens were most used for the treatment of anaemia. The plant with the highest prescription was Carica papaya for the treatment of malaria.
\end{abstract}

Keywords: Ethnobotany, Anti-anaemic, Haemostasis, Malaria, Tiv, Traditional medicine, Nigeria.

\section{INTRODUCTION}

The practice of traditional medicine depends majorly on the use of plants to treat diseases. The use of plants as medicine especially among rural-dwelling, low-income earners has continued to increase because plant materials are affordable and readily available. About $80 \%$ of African and Asian population are reported to be dependent on traditional medicine (Oyebode et al., 2016). For low-income earners, traditional medicine provides a convenient alternative to orthodox medicine which in some cases is either not affordable or not readily available (Igoli $e t$ al., 2011; Ladele \& Bisi-Amosun, 2014; Ichoron et al., 2019). Knowledge of traditional medicine and the plants used is usually transferred from the traditional medicine practitioners to their successors by word of mouth and vital information could be lost in the process (Alyegba et al., 2013). Ethnobotanical surveys thus present an opportunity to gather and document information on medicinal plants and how they are used by indigenous people. Such surveys also motivate the scientific investigation of plants with acclaimed medicinal activities. Ethnobotanical studies have proven to be the most viable way of identifying novel medicinal plants (Igoli et al., 2005; Awai \& Igoli, 2015; Nande \& Igoli, 2017; Ichoron et al., 2019). Anaemia is a global health problem affecting both developing and developed countries with consequences for human health and socio-economic development. About 1.62 billion people are affected globally, corresponding to $24.8 \%$ of the world's population (WHO, 2008). Plant-based traditional medicine plays an essential role in health care and drug discovery and medicinal folklore over the years has guided research that culminated into the discovery of several drugs (Cordell, 2000; Ghorbani, 2006).

There is evidence from oral tradition that the Tiv people of Nigeria have found ways to treat anaemia, induce haemostasis and treat several other ailments using medicinal plants. The efficacious and frequently prescribed plants may contain compounds that are potential drug candidates and could rightly be recommended for further examination. Gboko, Konshisha and Ushongo Local Government Areas where the study was conducted are in the Tiv speaking area of Benue State. They cover an area of about $4,581 \mathrm{~km}^{2}$ with an estimated population of 1.025 million people (National Population Commission, 2010; City Population, 2016). Orthodox medical care is not sufficiently available in these areas and in some cases, not affordable. There are only 113 public primary health facilities and two secondary health facilities in these local government areas (Ujoh \& Kwaghsende, 2014). The communities are agrarian and the population is rural. The vegetation is of the Guinea Savanna type with open grassland, scattered trees and shrubs. The climate is tropical, with dry and wet seasons. Wet seasons last from April to October while dry seasons last from November to March annually (Tyowua et al., 2013). The people rely largely on traditional medicine for their primary health care. The traditional medicine practitioners have assistants who usually take over from them in the event of death or old age. The assistants are usually family members. Knowledge is transferred from the masters to their assistants through apprenticeship. There are no published records of their methods. This study reports on the medicinal plants used for the 
treatment of anaemia, control of bleeding from cuts and wounds, and other diseases in these Tiv speaking areas of Benue State, Nigeria.

\section{MATERIALS AND METHODS}

\section{Data collection}

Data was collected through the administration of a structured questionnaire and oral interview of herbalists (traditional medicine practitioners) living and working in the areas. Information on local names of plants, parts of the plants used, method of preparation, route of administration and ailments treated were obtained from the respondents.

\section{Data analysis}

Following ethnobotanical Indices were employed to analyze the data, Use Value $(U V)$

The relevance of a plant species in the traditional medicine system of the study area was determined by a quantitative method called Use Value (UV). The UV was calculated using the formula,

$$
U V=\frac{\sum U i}{N}
$$

Where, $U i$ is the total number of informants that cited a given species, $\mathrm{N}$ is the total number of informants. High Use Value for a species indicates that the plant is highly used by the informants, which implies that the species is important in the traditional medicine practice of the study area (Ichoron et al., 2019).

\section{Fidelity Level (FL)}

Fidelity Level quantifies the importance of a species for the treatment of a given ailment. In this study, FL was used to identify the most preferred species by the herbalists for the treatments in the study area. FL was calculated using following formula,

$$
F L=\frac{I p}{I u} \times 100
$$

Where, $I_{P}$ is the number of informants, who cited the species for the treatment of a particular ailment, I $\underline{\mathrm{u}}$ is the total number of informants who mentioned the species for any use at all. The FL values range from $0<F L \leq 100$. High $F L$ values for a plant species indicate that it is frequently used or efficacious for the treatment of that specific ailment. On the other hand, low FL values indicate the low frequency of use or less effectiveness of the species in treating the ailment (Ouelbani et al., 2016).

\section{Informant Consensus Factor (ICF)}

ICF shows the extent of agreement among the informants on the plants used for the treatment of a specific ailment. In this study, it was calculated to determine the extent of agreement among the informants on the plants used in the study area. It was calculated using the formula,

$$
I C F=\frac{N u r-N t}{N u r-1}
$$

Where, $\mathrm{N}_{\mathrm{ur}}$ refers to the number of informants using the plant to treat a particular disease and Nt refers to the number of species used for the treatment of that particular disease by all informants. ICF values range from 0 to 1 . When plants are chosen randomly or there is no exchange of information on plant use among informants, the ICF approaches zero. If the value approaches 1 , then there is a well-defined selection criterion or information is exchanged between informants (Ichoron et al., 2019).

\begin{tabular}{|c|c|c|c|c|c|c|c|}
\hline S.N. & Scientific Name & $\begin{array}{l}\text { Local Name } \\
\text { (Tiv) }\end{array}$ & $\begin{array}{l}\text { Use } \\
\text { Value }\end{array}$ & Part Used & Method of Preparation & $\begin{array}{l}\text { Route of } \\
\text { Application }\end{array}$ & $\begin{array}{l}\text { Ailment } \\
\text { Treated }\end{array}$ \\
\hline \multicolumn{8}{|c|}{ Amaranthaceae } \\
\hline 1 & Amaranthus hybridus $\mathrm{L}$. & Aleofu & 0.68 & Leaves & $\begin{array}{l}\text { Leaves are eaten raw or } \\
\text { cooked as food }\end{array}$ & Oral & Anaemia \\
\hline \multicolumn{8}{|c|}{ Anacardiaceae } \\
\hline 2 & Mangifera indica $\mathrm{L}$. & Mangoo & 0.83 & Stem bark & $\begin{array}{l}\text { Stem bark is boiled to obtain } \\
\text { aqueous extract }\end{array}$ & Oral & Anaemia \\
\hline 3 & Spondias mombin L. & Konkuaa & 0.80 & Stem bark & $\begin{array}{l}\text { Bark of plant is peeled off, } \\
\text { washed and then boiled in } \\
\text { clean water to obtain extract }\end{array}$ & Oral & Catarrh, Cold \\
\hline 4 & Spondias mombin $\mathrm{L}$. & Konkuaa & 0.80 & fruits & $\begin{array}{l}\text { The mesocarp is eaten raw } \\
\text { from the whole fruit }\end{array}$ & Oral & Scurvy \\
\hline
\end{tabular}

\section{RESULTS}

Table 1. Plant species identified and their use. 
Apocynaceae

\section{Landolphia owariensis P. Pungwa Beauy}

Arecaceae

$6 \quad$ Elaies guineensis Jacq. Ivile/lkye $\quad 0.52$ sap

Aspaeagaceae

$7 \quad$ Dracaena fragrans (L.) Ker Chilakem Gawl.

\author{
Asteraceae \\ 8 Aspilia Africana (Pers.) Oso-Oso \\ C.D.Adams \\ 9 Chromolaena odorata (L.) Bokpai \\ R.M.King \& H.Rob. \\ 10 Tridax procumbens (L.) L. - \\ 11 Vernonia amygdalina Ityuna \\ Delile \\ Bignoniaceae

$\begin{array}{ll}12 & \begin{array}{l}\text { Kigelia africana (Lam.) } \\ \text { Benth. }\end{array} \\ 13 & \begin{array}{l}\text { Newbouldia laevis (P. } \\ \text { Beauv.) Seem. }\end{array}\end{array}$

0.98 Leaves

0.82 Leaves, stem bark

0.57 Roots

$0.87 \quad$ Leaves

14 Stereospermum kunthianum Umanatumba Cham.

Caricaceae

15 Carica papaya L.

Mbue

0.99 Leaves

16 Parkia biglobosa (Jacq.) Nune

G.Don

0.89 Stem bark

Leaves are washed in clean

water and then boiled to

Oral

obtain extract

of the palm tree to tap sap

and drank

Leaves are boiled with the Oral

tender twigs of Vitex

doniana Sweet

Fresh leaves from tender

twigs are squeezed to obtain

juice which is then applied

on the wound to stop

bleeding

0.88 Leaves

Leaves and stems are

collected and squeezed to

obtain extract

Leaves are crushed and

macerated to obtain aqueous

extract at room temperature

Oral

Anaemia

Oral

Anaemia

0.53 Leaves and Stem bark and leaves are stem bark boiled to obtain aqueous extract

0.83 Leaves and Stem bark and leaves are stem bark boiled to obtain aqueous extract

Oral

Filariasis, Anaemia

Oral

0.72 Stem and Stem and leaves are boiled in Oral leaves water to obtain extract

Leaves are macerated at

Oral room temperature to obtain aqueous extract

Piliostigma thonningii Nyihar

0.66 Leaves

(Schum.) Milne-Redh.

Stem bark is dried and

pulverized into a fine

Topical

Powder

Leaves are boiled in water to Oral

obtain aqueous extract

Ceasalpinioideae

18 Burkea Africana Hook

Gbagbongom

0.49 Stem bark

Stem bark is removed and

Oral

boiled in clean water to

obtain extract

Cochlospermaceae

19 Cochlospermum planchonii Kpavande Hook.f. ex Planch.

0.93 Roots

Fresh roots are boiled to obtain aqueous extract

Oral

Typhoid

fever,

Anaemia, convulsion

Typhoid

fever

Malaria

Combretaceae

20 Terminalia schimperiana Kuegh Hochst. ex Deile

0.67 Roots, stem Boiled in to obtain aqueous Oral bark and extract

leaves

Convolvulaceae

21 Ipomoea batatas (L.) Lam. Atsaka
0.63 Leaves
Tooth infection

Hemorrhage

Gonorrhea

Hemorrhage 
Cucurbitaceae

22 Telfairia occidentalis Hook Ugwu f.

Cyperaceae

23 Scleria latifolia Sw.

Suswam

0.43 Leaves

Ahina

Euphorbiaceae

24 Alchornea cordifolia (Schumach. \& Thonn.)

Mull.Arg. Antidesma venosum E.Mey. Baverakpua ex Tul.

27

28 Jatropha curcas L.

29

Jatropha tanjorensis J.L. Kon-Awambe 0.98 Leaves Ellis \& Saroja

30

Manihot esculenta Crantz. Logo

0.97 Leaves
Aqueous leaf extract is obtained by at room

temperature

Aqueous leaf extract is obtained by maceration at room temperature

Leaves are boiled to obtain aqueous extracted

0.55 Stem bark

Fresh stem bark is grounded together with pepper into a fine paste and eaten

Roots are boiled in water to Ora obtain aqueous extract

Gbatsombu 0.27 Whole plant Boiled in a concoction with Oral other plants

Stems are cut into pieces, washed and boiled to obtain

Oral extract

Fresh leaves are washed in in Oral clean water and squeezed to

obtain aqueous extract

Leaves from tender twigs are Oral boiled for about 15 minutes and eaten whole

Leguminosae

31 Cassia occidentalis

32 Daniellia oliveri (Rolfe) Hutch. \& Dalziel

Tsetsa

Chiha/Chaha

33 Erythrophleum suaveolens Kor (Guill. \& Perr. Brenan)

34 Mucuna pruriens (L.) DC.

35 Mucuna sloanei Fawc. \& Kor Rendle.

36

Tephrosia vogelii Hook.f. Kuhwa

Lamiaceae

37 Gmelina arborea Roxb. Malina

38

Ocimum gratissimum L.

Kungureku- $0.98 \quad$ Leaves

Tamen

39 Ocimum gratissimum L.

Kunguraku- $0.67 \quad$ Leaves

Tamen

Malvaceae

$40 \quad$ Hibiscus sabdariffa L.

$41 \quad$ Sterculia setigera Delile

Ashwe-U-

Nyian

Kumenduur

Meliaceae

42 Azadirachta indica L. Neem

Moraceae

43 Ficus thonningii Blume. Akinde

$44 \quad$ Ficus sycomorus L.
Tur

0.66 Whole plant Boiled in water to obtain extract

0.43

Tender twigs

\subsection{Roots}

0.83 Leaves

0.77 Leaves

Tender twigs are washed in

clean water and boiled to

obtain extract

Roots are boiled to obtain

aqueous extract

Maceration

Leaves

0.44 Leaves

Leaves are washed and squeezed to obtain juice

0.80 Stem bark, Decoction or Maceration leaves

Leaves are crushed and squeezed to obtain juice Boiled in water to obtain aqueous extract

$\begin{array}{cl}0.70 & \begin{array}{l}\text { Fruit and } \\ \text { calyx }\end{array} \\ 0.56 & \text { Stem bark }\end{array}$

Decoction

Oral

Oral

Oral

Oral

Leaves are

boiled to

extract juice

Oral

Dermatitis

Oral, Inhaling Anaemia, vapour from Fever, boiling Malaria, decoction Catarrh Oral Hemorrhage

Oral Typhoid fever

Anaemia

Toothache boiled in clean water to obtain extract

0.88 Heartwood, The branches are cut into Ora

Typhoid fever stem bark small pieces and mixed with and leaves its leaves and

0.30 Tender The tender twigs are cooked Oral twigs and eaten whole

0.30 Leaves from Boiled for about 15 minutes Oral tender twigs and eaten whole
Hemorrhage

Hemorrhage 


\begin{tabular}{|c|c|c|c|c|c|c|c|}
\hline \multicolumn{8}{|c|}{ Moringaceae } \\
\hline 45 & Moringa oleifera Lam. & Jegeregede & 0.81 & Leaves & $\begin{array}{l}\text { Leaves are squeezed to } \\
\text { obtain juice }\end{array}$ & $\begin{array}{l}\text { Drops in the } \\
\text { eye }\end{array}$ & Conjunctivitis \\
\hline \multicolumn{8}{|c|}{ Musaceae } \\
\hline 46 & Musa sapientum L. & Ayaba & 0.35 & $\begin{array}{l}\text { Stems and } \\
\text { leaves }\end{array}$ & $\begin{array}{l}\text { Stems and leaves are } \\
\text { macerated in cold water and } \\
\text { taken orally }\end{array}$ & Oral & Hypertension \\
\hline \multicolumn{8}{|c|}{ Poaceae } \\
\hline 47 & $\begin{array}{l}\text { Cymbopogon citratus (DC.) } \\
\text { Stapf }\end{array}$ & Tohogile & 0.36 & Leaves & $\begin{array}{l}\text { Leaves and stems are } \\
\text { washed, boiled in clean } \\
\text { water to obtain an extract }\end{array}$ & Oral & Typhoid fever \\
\hline 48 & Imperata cylindrica $(\mathrm{L})$. & Ihira & 0.43 & Leaves & $\begin{array}{l}\text { Leaves are crushed and } \\
\text { macerated to obtain aqueous } \\
\text { extract at room temperature }\end{array}$ & Oral & Hemorrhage \\
\hline 49 & $\begin{array}{l}\text { Pennisetum pedicellatum } \\
\text { Trin }\end{array}$ & Alufu & 0.67 & Leaves & $\begin{array}{l}\text { Leaves are boiled in water to } \\
\text { obtain aqueous extract }\end{array}$ & Oral & Hemorrhage \\
\hline 50 & $\begin{array}{l}\text { Sorghum bicolor }(\mathrm{L} .) \\
\text { Moench }\end{array}$ & Wua & 0.33 & $\begin{array}{l}\text { Root, stem } \\
\text { and Leaves }\end{array}$ & $\begin{array}{l}\text { Roots, stem and leaves are } \\
\text { boiled in water for } 1-2 \text { hours } \\
\text { to obtain extract }\end{array}$ & Oral & $\begin{array}{l}\text { Typhoid } \\
\text { fever }\end{array}$ \\
\hline \multicolumn{8}{|c|}{ Rubiaceae } \\
\hline 51 & $\begin{array}{l}\text { Borreria ocymoides } \\
\text { (Burm.f.) DC. }\end{array}$ & Ateiwa & 0.87 & Leaves & $\begin{array}{l}\text { Fresh leaves are squeezed to } \\
\text { extract juice }\end{array}$ & Topical & Eczema \\
\hline 52 & Nauclea latifolia $\mathrm{Sm}$. & Ikura-Ukase & 0.92 & $\begin{array}{l}\text { Roots and } \\
\text { Leaves }\end{array}$ & $\begin{array}{l}\text { Roots and Leaves are } \\
\text { crushed and extracted in cold } \\
\text { water }\end{array}$ & Oral & Measles \\
\hline 53 & $\begin{array}{l}\text { Sarcocephalus latifolius } \\
\text { (Sm.) E.A.Bruce }\end{array}$ & Horkura & 0.45 & Stem bark & $\begin{array}{l}\text { Stem bark is boiled to obtain } \\
\text { aqueous extract }\end{array}$ & Oral & $\begin{array}{l}\text { Stomach } \\
\text { pains }\end{array}$ \\
\hline \multicolumn{8}{|c|}{ Rutaceae } \\
\hline 54 & Citrus aurantifolia Pers & $\begin{array}{l}\text { Agbenge- } \\
\text { Alum }\end{array}$ & 0.65 & Fruit & $\begin{array}{l}\text { Fruits are sliced and } \\
\text { squeezed to extract juice }\end{array}$ & Oral & $\begin{array}{l}\text { Amoebic } \\
\text { dysentery }\end{array}$ \\
\hline \multicolumn{8}{|c|}{ Sapotaceae } \\
\hline 55 & $\begin{array}{l}\text { Vitellaria paradoxa } \\
\text { Gaeertn }\end{array}$ & Chamegh & 0.44 & Stem bark & $\begin{array}{l}\text { Bark is removed, dried and } \\
\text { ground into powder }\end{array}$ & $\begin{array}{l}\text { Oral; powder } \\
\text { is licked }\end{array}$ & $\begin{array}{l}\text { Stomach } \\
\text { pains }\end{array}$ \\
\hline \multicolumn{8}{|c|}{ Zingiberaceae } \\
\hline 56 & Zingiber officinale Roscoe & Seta & 0.82 & Rhizome & $\begin{array}{l}\text { The outer covering of the } \\
\text { rhizome is scrapped off }\end{array}$ & $\begin{array}{l}\text { Rhizome is } \\
\text { chewed }\end{array}$ & $\begin{array}{l}\text { Cough and } \\
\text { catarrh }\end{array}$ \\
\hline
\end{tabular}

Fifty-six plant species belonging to twenty-nine families were identified as being used in the study area by traditional medicine practitioners. Table 1 summarizes the plant name, family, local name, ailment treated and Use Value; Table 2 shows Fidelity Level and Informant Consensus Factor. Prescriptions for treatment of twenty-one ailments were recorded. The most frequently mentioned ailments were anaemia, hemorrhage and typhoid fever. The majority of remedies were administered orally, leaves were used the most and boiling in water to obtain aqueous extracts or decoction was the most frequently preferred mode of the formulation.

Table 2. Informant Consensus Factors (ICF) and Fidelity Level (FL) for diseases treated with medicinal plants in the study area.

\begin{tabular}{|c|c|c|c|c|c|c|c|}
\hline S.N. & Ailment & ICF & Preferred Species & Part Used & Method of Preparation & $\begin{array}{l}\text { Route of } \\
\text { Administration } \\
\end{array}$ & FL (\%) \\
\hline 1 & Anaemia & 1.0 & $\begin{array}{l}\text { Jatropha tanjorensis } \\
\text { J.L. Ellis \& Saroja }\end{array}$ & leaves & $\begin{array}{l}\text { Fresh leaves are washed in } \\
\text { in clean water and squeezed } \\
\text { to obtain aqueous extract }\end{array}$ & Oral & 98.00 \\
\hline 2 & $\begin{array}{l}\text { Cold and } \\
\text { catarrh }\end{array}$ & 0.98 & $\begin{array}{l}\text { Zingiber officinale } \\
\text { Roscoe }\end{array}$ & Rhizome & $\begin{array}{l}\text { Rhizome is washed with } \\
\text { clean water, blended and } \\
\text { made into a n aqueous } \\
\text { solution }\end{array}$ & Oral & 93.00 \\
\hline 3 & Scurvy & 0.86 & $\begin{array}{l}\text { Spondias mombin } \\
\text { Linn. }\end{array}$ & fruit & $\begin{array}{l}\text { The mesocarp is eaten raw } \\
\text { from the whole plant }\end{array}$ & Oral & 79.00 \\
\hline 4 & Gonorrhea & 0.66 & $\begin{array}{l}\text { Landolphia } \\
\text { owariensis P. Beauy }\end{array}$ & Roots & $\begin{array}{l}\text { Roots are washed, boiled in } \\
\text { clean water to obtain } \\
\text { aqueous extract }\end{array}$ & Oral & 55.00 \\
\hline 5 & Measles & 0.57 & $\begin{array}{l}\text { Elaies guineensis } \\
\text { Jacq. }\end{array}$ & Sap & $\begin{array}{l}\text { Bored a hole in the growing } \\
\text { part of stem and pipes are } \\
\text { inserted to collect sap }\end{array}$ & $\begin{array}{l}\text { Sap is drank and used } \\
\text { for bath }\end{array}$ & 55.00 \\
\hline 6 & Stomach pains & 0.68 & Jatropha curcas L. & Stem & $\begin{array}{l}\text { Stems are cut into pieces, } \\
\text { washed and boiled to obtain } \\
\text { aqueous extract }\end{array}$ & Oral & 64.00 \\
\hline
\end{tabular}




\begin{tabular}{|c|c|c|c|c|c|c|c|}
\hline 7 & Hermorrhage & 0.98 & $\begin{array}{l}\text { Ocimum gratissimum } \\
\text { L. }\end{array}$ & leaves & $\begin{array}{l}\text { Leaves are washed and } \\
\text { squeezed to obtain juice }\end{array}$ & $\begin{array}{l}\text { Juice is applied } \\
\text { topically on bleeding } \\
\text { site }\end{array}$ & 43.00 \\
\hline 8 & $\begin{array}{l}\text { Amoebic } \\
\text { dysentery }\end{array}$ & 0.58 & $\begin{array}{l}\text { Citrus aurantifolia } \\
\text { Pers }\end{array}$ & fruit & $\begin{array}{l}\text { Fruits are sliced and } \\
\text { squeezed to extract juice }\end{array}$ & Oral & 72.00 \\
\hline 9 & Typhoid fever & 0.76 & $\begin{array}{l}\text { Sorghum bicolor }(\mathrm{L} .) \\
\text { Moench }\end{array}$ & $\begin{array}{l}\text { Root, stem } \\
\text { and leaves }\end{array}$ & $\begin{array}{l}\text { Leaves, stems and roots are } \\
\text { boiled together to obtain } \\
\text { aqueous extract }\end{array}$ & Oral & 77.00 \\
\hline 10 & Convulsion & 0.72 & $\begin{array}{l}\text { Newbouldia laevis } \\
\text { laevis (P. Beauv.) } \\
\text { Seeman ex Bureau. }\end{array}$ & $\begin{array}{l}\text { Leaves and } \\
\text { stem bark }\end{array}$ & $\begin{array}{l}\text { Stem bark and leave are } \\
\text { boiled aqueous extract }\end{array}$ & Oral & 66.00 \\
\hline 11 & Malaria & 0.23 & $\begin{array}{l}\text { Gmelina arborea } \\
\text { Roxb. }\end{array}$ & $\begin{array}{l}\text { Stem bark, } \\
\text { leaves }\end{array}$ & Decoction & $\begin{array}{l}\text { Inhaling vapour from } \\
\text { boiling decoction }\end{array}$ & 34.00 \\
\hline 12 & Jaundice & 0.34 & $\begin{array}{l}\text { Piliostigma } \\
\text { thonningii (Schum.) } \\
\text { Milne-Redh. }\end{array}$ & Leaves & $\begin{array}{l}\text { Leaves are boiled in clean } \\
\text { water to obtain aqueous } \\
\text { extract }\end{array}$ & Oral & 43.00 \\
\hline 13 & $\begin{array}{l}\text { External } \\
\text { wound }\end{array}$ & 0.56 & $\begin{array}{l}\text { Parkia biglobosa } \\
\text { (Jacq.) G.Don }\end{array}$ & Stem bark & $\begin{array}{l}\text { Stem bark is dried and } \\
\text { blended into powder. }\end{array}$ & Topical on the wound & 84.00 \\
\hline 14 & Toothache & 0.49 & $\begin{array}{l}\text { Burkea Africana } \\
\text { Hook }\end{array}$ & Stem bark & $\begin{array}{l}\text { Fresh stem bark is boiled in } \\
\text { water to obtain aqueous } \\
\text { extract }\end{array}$ & Oral & 65.00 \\
\hline 15 & Cholera & 0.66 & $\begin{array}{l}\text { Bridelia ferruginea } \\
\text { Benth }\end{array}$ & Roots & $\begin{array}{l}\text { Fresh roots are boiled in } \\
\text { water to obtain aqueous } \\
\text { extract }\end{array}$ & Oral & 71.00 \\
\hline 16 & Conjunctivitis & 0.81 & $\begin{array}{l}\text { Moringa oleifera } \\
\text { Lam. }\end{array}$ & Leaves & $\begin{array}{l}\text { Leaves are squeezed to } \\
\text { obtain juice }\end{array}$ & $\begin{array}{l}\text { Juices is applied } \\
\text { directly into the eye }\end{array}$ & 92.00 \\
\hline 17 & Dermatitis & 0.67 & $\begin{array}{l}\text { Tephrosia vogelii } \\
\text { Hook.f. }\end{array}$ & Leaves & $\begin{array}{l}\text { Leaves are washed and } \\
\text { squeeze to obtain juice }\end{array}$ & Topical & 76.00 \\
\hline 18 & $\begin{array}{l}\text { Intestinal } \\
\text { worms }\end{array}$ & 0.79 & Antides mavenusum & Stem bark & $\begin{array}{l}\text { Fresh stem bark is blended } \\
\text { together with fresh pepper } \\
\text { into a fine paste and eaten }\end{array}$ & Oral & 84.00 \\
\hline 19 & Hypertension & 0.88 & Musa sapientum L. & $\begin{array}{l}\text { Stems and } \\
\text { leaves }\end{array}$ & $\begin{array}{l}\text { Stems and leaves are } \\
\text { macerated in water at room } \\
\text { temperature and taken } \\
\text { orally }\end{array}$ & Oral & 91.00 \\
\hline 20 & Menorrhagia & 0.85 & $\begin{array}{l}\text { Dracaena fragrans } \\
\text { (L.) Ker Gawl. }\end{array}$ & Leaves & $\begin{array}{l}\text { Leaves are boiled together } \\
\text { with leaves from tender } \\
\text { twigs of Vitex doniana }\end{array}$ & Oral & 86.00 \\
\hline 21 & Infertility & 0.92 & Vitex doniana Sweet & Fruits & $\begin{array}{l}\text { Mesocarp of fruit is eaten } \\
\text { raw }\end{array}$ & Oral & 87.00 \\
\hline
\end{tabular}

\section{DISCUSSION AND CONCLUSION}

This study confirmed that plants are very important and used extensively in traditional medicine within the Tiv speaking area of Benue State (Awai \& Igoli 2015; Ichoron et al., 2019). The plants most frequently prescribed from this study were Jatropha tanjorensis J.L. Ellis \& Saroja, Vernonia amygdalina Delile, Telfairia occidentalis Hook. f., and Mucuna pruriens (L.) DC. These plants are efficacious for the treatment of anaemia as there is uniformity among the informants about their use. Ocimum gratissimum L., Cochlospermum planchonii Hook. f. ex Planch., Tridax procumbens $(\mathrm{L}$.) L. were the most used for haemostasis. These findings show that traditional medicine has knowledge about plants and their potentials as medicines. These plants can be investigated for drug leads in the continued search for new drugs for anaemia and other ailments.

\section{ACKNOWLEDGEMENTS}

We acknowledge the cooperation of our respondents who gave us useful information that culminated into the results that are published here. We also gratefully acknowledge the inputs of the reviewers.

\section{REFERENCES}

Alyegba S.S., Dagba M.R. \& Ioryem B. (2013). Ethnobotanical Survey of Edible Wild Plants in Tiv Communities of Benue State, Nigeria. Journal of Natural Sciences Research, 3(7): 17-23.

Awai E.P. \& Igoli J.O. (2015). Medicinal Plants used in Antenatal and Perinatal Care Among the Tiv people of Benue State, Nigeria. Indo Global Journal of Pharmaceutical Science, 5(1): 90-93.

City Population (2016). Statistics, maps and charts. Retrieved from: https://citypopulation.de/php/nigeria-admin.php

Cordell G. (2000). Biodiversity and Drug Discovery: A Symbiotic Relationship. Phytochemistry, 55: 463-480.

Ghorbani A., Naghibi F. \& Mosaddegh M. (2006). Ethnobotany, Ethnopharmacology and Drug Discovery. Iranian Journal of Pharmaceutical Sciences, 2(2): 109-118. 
Ichoron N., Tyoer S., James E.J. \& Igoli J.O. (2019). A survey of Medicinal Plants Used as Traditional Medicine in Ukum and Ogbadibo Local Government Areas of Benue state, Nigeria. Plants and Environment, 1(1): 5-11.

Igoli J.O., Ogaji O.G., Tor-Anyiin T.A. \& Igoli N.P. (2005). Traditional Medicine Practice Amongst the Igede People of Nigeria. Part II. African Journal of Traditional, Complementary and Alternative Medicines, 2(2): 134-152.

Igoli J.O., Tsenongo S.N. \& Tor-Anyiin T. A. (2011). A Survey of Anti-venomous, Toxic and other plants used in some parts of Tivland, Nigeria. International Journal of Multi-aspectual Practice, 1(3): 240-244.

Ladele A.A. \& Bisi-Amosun O.O. (2014). Level of Utilization of Traditional and Orthodox Medicines by Rural Dwellers in Ile-Ogbo Community of Osun State, Nigeria. Journal of Agricultural Extension, 18(1): 155-168.

Nande W.U. \& Igoli J.O. (2017). Isolation and Characterization of Bioactive Compounds from Plant Materials: The Nigerian Situation. Nigerian Journal of Pure and Applied Science, 9(1): 132-143.

National Population Commission (2010). 2006 Population and Housing Census Priority Table Volume IV Population Distribution by Age \& Sex (State \& Local Government Area). Retrieved from: https://searchworks.stanford.edu/view/ 8626165.

Ouelbani R., Bensari S., Mouas T.N. \& Khelifi D. (2016). Ethnobotanical Investigations on Plants Used in Folk Medicine in the Regions of Constantine and Mila (North-East of Algeria). Journal of Ethnopharmacology, 194: 196-218.

Oyebode O., Kandala N., Clinton P.J. \& Lilford R.J. (2016). Use of Traditional Medicine in Middle-Income Countries: a WHOSAGE Study. Health Policy and Planning, 31(8): 984-991.

Tyowua B.T., Agbelusi E.A. \& Dera B.A. (2013). Evaluation of Vegetation Types and Utilization in Wildlife Park of the University of Agriculture Makurdi, Nigeria. General Journal of Agricultural Science, 3(1): 1-5.

Ujoh F. \& Kwaghsende F. (2014). Analysis of the Spatial Distribution of Health Facilities in Benue State, Nigeria. Public Health Research, 4(5): 210-218.

WHO (2008). Worldwide prevalence of anaemia 1993-2005: WHO global database on anaemia. Retrieved from: http://apps.who.int/iris/bitstream/10665/43894/1/9789241596657_eng.pdf 